\title{
HALLOYSITE NANOTUBES: DESIGN, CHARACTERIZATION AND APPLICATIONS. A REVIEW
}

\author{
REVATI DHARAMPAL SAGARE ${ }^{1 \#}$, FATIMA SANJERI DASANKOPPA ${ }^{2 *}$, H. N. SHOLAPUR ${ }^{3 \#}$, \\ KEZIA BURGA ${ }^{4}$
}

${ }^{I}$ PhD. Student, Department of Pharmaceutics, Discipline of Pharmacy, KLE College of Pharmacy, Hubballi, India

${ }^{2}$ Department of Pharmaceutics, Faculty of Pharmacy, KLE College of Pharmacy, Hubballi, India

${ }^{3}$ Department of Pharmacognosy, Faculty of Pharmacy, KLE College of Pharmacy, Hubballi, India

${ }^{4}$ Scientific research assistant, Department of Chemistry, University of Warsaw, Warsaw, Poland

*corresponding author: fsdasankop@ gmail.com

${ }^{*}$ Authors with equal contribution.

Manuscript received: May 2020

\begin{abstract}
Halloysite nanotubes (HNTs) have several exciting potential applications in polymer nanocomposites. These are naturally sourced nanomaterials obtained from the mines as a natural deposit. The hollow tubular nanostructure with biocompatibility, environmental friendly and low-cost possessing makes halloysite as trendsetter in green nanotechnology. These are composed of double-layered, aluminosilicate minerals with an ultra-tiny hollow tubular structure in submicron range. The specific characteristics of HNTs lead to plentiful range of applications in environmental sciences, dye removal, anticorrosive coatings, in cosmetics, flame retardants, forensic science, etc. HNTs display remarkable thermal stability, faster adsorption rates, tuneable release rates, excellent drug encapsulation, biocompatibility, mechanical properties and ease of availability, therefore with numerous pharmaceutical applications. Nanomedical applications are gene delivery, tissue engineering, cancer and stem cells isolation and bio-imaging. This review is focused on the detailing HNTs for its structure features, functionalization methods, drug loading and their versatile applications.
\end{abstract}

\section{Rezumat}

Nanotuburile din haloizit (NHT) prezintă o serie de aplicații interesante cu potențial în domeniul nanocompozitelor polimerice. Acestea sunt nanomateriale naturale obținute din depozitele naturale miniere. Structura nanotubulară goală pe interior ce prezintă proprietăți biocompatibile, benefice mediului înconjurător și costuri reduse sunt principalele avantaje ale halozitului ca și nanotehnologie verde. Acestea sunt compuse din minerale aluminosilicate bistratificate, cu o structură tubulară submicronică, goală pe interior și cu diametru mic. Caracteristicile acestora determină o gamă variată de aplicații în domeniul științelor mediului, pentru îndepărtarea coloranților, a învelișurilor anticorozive, în industria cosmetică, în domeniul produselor ignifuge, în criminalistică etc. Nanotuburile de haloizit prezintă stabilitate termică pronunțată, viteză de absorbție ridicată și eliberare rapidă ce poate fi potențată, excelente proprietăți de încapsulare a substanțelor medicamentoase, biocompatibilitate, bune proprietăţi mecanice și biodisponibilitate, găsindu-și numeroase aplicații în domeniul farmaceutic. Utilizările nanomedicale se regăsesc în terapia genică, în domeniul ingineriei tisulare, în izolarea celulelor stem și a celor canceroase și în bioimagistică. Articolul sintetizează cele mai noi informații referitor la nanotuburile de haloizit, respectiv a caracteristicilor structurale, a funcționalizării, a capacității de încărcare cu substanțe medicamentoase, precum și a utilizărilor versatile ale acestora.

Keywords: halloysite nanotubes (HNTs), biocompatible, cosmetics, gene drug delivery

\section{Introduction}

In the field of nanotechnology, various nanomaterials are used like carbon nanotubes, nanofluids, nanoemulsions, nanocapsules etc. Due to their harmful effects, these nano materials are not designed safe for individuals and for the environment as well [37]. Green nanotechnology is one of the promising technologies that aims in advancing environment safe and less harmful nanoproducts. HNTs, nanocomposites and nanopowders etc. are now emerging as trendsetter in green nanotechnology [14]. These are biocompatible and feasible carrier for the incorporation of biologically active molecules due to the hollow space inside the tubular structure [8]. HNTs are novel 1D naturally occurring clay minerals having the similar chemical composition as kaolinite [30].

They belong to the class of aluminosilicate clays, with molecular formula $\left(\mathrm{Al}_{2} \mathrm{Si}_{2} \mathrm{O}_{5}(\mathrm{OH})_{4} * 2 \mathrm{H}_{2} \mathrm{O}\right)$ exhibiting a hollow nanotubular structure [4] with their length ranging from $400-1000 \mathrm{~nm}$, the inner and outer diameters of the nanotubes varying from $10-40 \mathrm{~nm}$ and $40-80 \mathrm{~nm}$ (Figure 1). The high aspect ratio (length/diameter) ranges from 10 - $50 \mathrm{~nm}$ [5]. HNTs are 1:1 phyllosilicates with six-membered rings, the atoms are arranged to form a structure of one octahedral and one tetrahedral sheet [45]. HNTs contain two types of hydroxyl groups, an inner one and an 
outer one, which are placed between the layers, respectively on the surface of the nanotubes. The outer surface of HNTs is mainly formed by siloxane ( $\mathrm{Si}-\mathrm{O}-\mathrm{Si}$ ) groups, and the inner lumen surface is composed of aluminol groups (Al-OH) groups, making them Gibbsite-like highly hydrophilic (where Gibsitelike already relates to the monoclinic crystallography and the prismatic aspect of the crystals), the edges of the HNTs consists of Al-OH and Si-OH groups [32], (Figure 2). Hence, the inner surface of HNTs is chemically active, whereas the outer surface is considered as non-reactive [6]. Taking into consideration the state of hydration, HNTs are broadly classified into two groups: hydrated HNTs with a crystalline structure of $10 \AA \mathrm{d}_{001}$ spacing and the dehydrated HNTs with $7 \AA \mathrm{d}_{001}$ spacing. As it has been reported, that the existence or the age of interlayer water in HNTs is one of the most significant features differentiating HNTs from kaolinite [12].

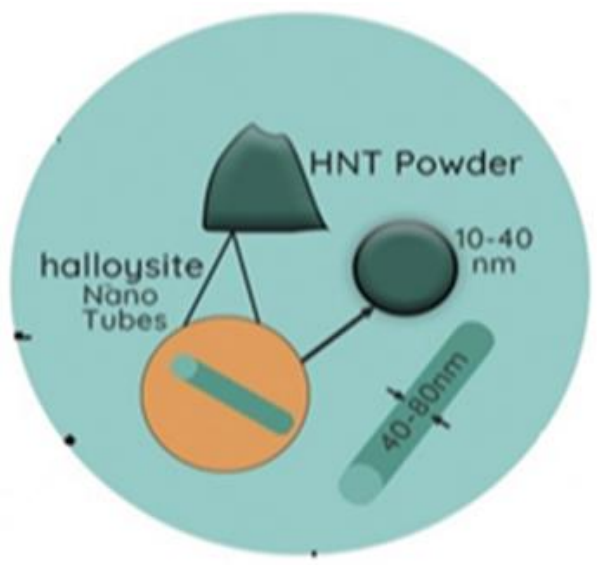

Figure 1.

Halloysite Nanotubular Structure (inner diameter $=10-40 \mathrm{~nm}$; outer diameter $=40-80 \mathrm{~nm}$ )

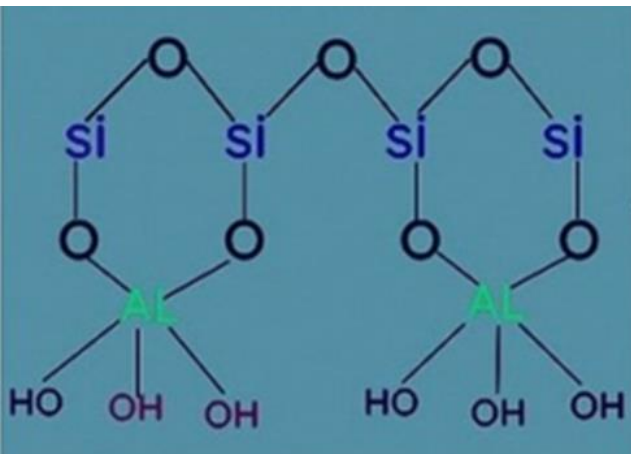

Figure 2.

Molecular Structure of HNT

HNTs consisting of $\mathrm{Al}-\mathrm{OH}$ and $\mathrm{Si}-\mathrm{OH}$ groups exhibiting the monolayer of water molecule

\section{Physicochemical properties of HNTs}

Physical properties of HNTs are presented in Table I [29].
Table I

Physical properties of HNTs [29]

\begin{tabular}{lc}
\hline \multicolumn{1}{c}{ Parameter } & Values \\
\hline Density & $2.14-2.53 \mathrm{~g} / \mathrm{cm}^{3}$ \\
Average Pore Size & $80-100 \AA$ \\
Typical Surface Area & $22.1-81.6 \mathrm{~m}^{2} * \mathrm{~g}$ \\
Pore volume & $1.25 \mathrm{~mL} * \mathrm{~g}$ \\
Aspect Ratio (L/D) & $9-50 \mathrm{~nm}$ \\
Specific gravity & $2.53 \mathrm{~g} / \mathrm{cm}^{2}$ \\
Cation exchange capability & $0.1-0.7 \mathrm{~mol} * \mathrm{~kg}$ \\
\hline
\end{tabular}

\section{Chemical Properties [34]}

The outer surface of the HNTs has the similar properties to $\mathrm{SiO}_{2}$ having a negative charge at $\mathrm{pH} 6$ - 7 (zeta potential $-18 \mathrm{mV}$ ), whereas the inner cylinder core is related to $\mathrm{Al}_{2} \mathrm{O}_{3}$ which is positively charged. The positive charge of the inner lumen urges the loading of HNTs with negative macromolecules within the void spaces. Negatively charged molecules are repelled by the negative charge present on the outer surface of HNTs.

\section{Advantages of HNTs}

HNTs are natural, non-toxic, biocompatible, ecofriendly and low-cost material, and it is recognized as nanomaterials (EPA 4) by the Environmental Protection Agency [40]. They have fine particle size and elegant dispersion property in matrix [15]. HNTs are capable of inhibiting the release, unless triggered and tunable release rates are achieved [38]. They possess immense cation exchange capacity [12]. A halloysite nanotube is able to load multiple active agents simultaneously [50]. It maintains constant, sustained release rates and not requiring an initial over-dosage [11, 14, 38]. HNTs have high aspect ratio, immense porosity and non-swelling nature [11]. During harsh material processing, halloysite protects active agent within its lumen [14]. It has remarkable loading rates compared to other carriers [11]. Halloysite has regeneration ability and enriches the bone healing efficacy [38]. HNTs have fast adsorption rate and high adsorption capacity [11] and HNTs can be used in many forms such as powders, creams, gels, lotions and sprays [21]. Solubility and Stability of HNTs

Solubilization and dispersion study of HNTs was performed by Mohtashim HS et al. without using organic solvents, to have a supramolecular product of HNTs and DNA [33]. A long-term stability study for natural HNTs was carried out at room temperature in three different solutions: strong acids (e.g., sulphuric acid, hydrochloric acid and acetic acid), strong base (e.g., sodium hydroxide) and distilled water. Both the acidic and basic environments reinforce the mechanism of nanotubes transformation to propose the dissolution of HNTs and precipitation of stable forms of amorphous $\mathrm{Al}(\mathrm{OH})_{3}$ and $\mathrm{SiO}_{2}$, respectively [46]. 


\section{Functionalization of HNTs}

Among the various phyllosilicate nanomaterials (silicate based layer structure) such as kaolin and montmorillonite, halloysite has some prominent advantages. HNTs are composed of small tubes that allow removal of nanoparticles from a living organism. The active molecules can be incorporated into the lumen of an empty HNTs or even drug can be absorbed onto the outer surface of HNTs.

The chemical modification can be introduced into the external surface of the HNTs; whereas the lumen of the HNTs can simultaneously function by initiating supramolecular interactions of the drugs with the lumen of HNTs. The inner lumen is the most enticing feature of HNTs, with a diameter capable of entangling the chemical agents such as drugs, DNA, nanomolecules and nanodots and other chemically active agents e.g., anticorrosion for protective coating [31].

The optimized properties of nanocomposites are obtained by advancing the nano dispersion and stress transfer. The interfacial interaction between the nanotubes and the polymer, should be carefully governed [41]. In other respects, impoverished load transfer among the nanotubes and circumferential polymer chain may induce interfacial spillage and reduces the mechanical properties of the composites. Thus, the functionalization of HNTs is highly essential for processing and increasing the properties of HNTs polymer nanocomposites, (Figure 3 ). The modified polymer nanocomposites nanotubes reveal enhanced mechanical and thermal properties, as the functionalization advances the dispersal and stress transfer [24].

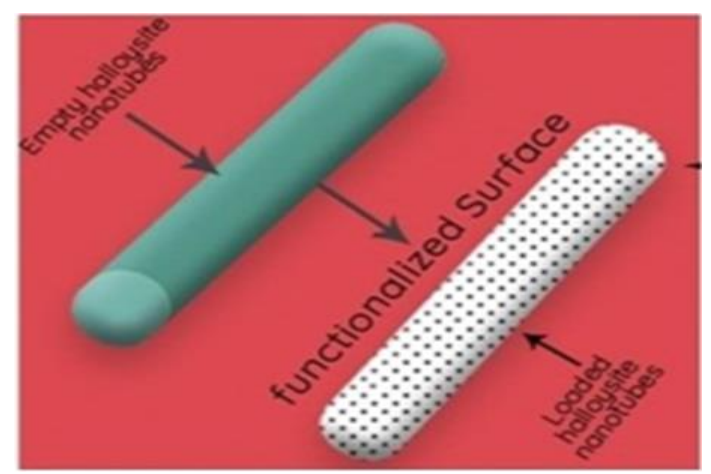

Figure 3.

Functionalization of HNTs
The functionalization of HNTs is achieved by two different processes, as follows.

Covalent functionalization

The inner surfaces and the edges of the sheets consist of hydroxyl group leading to the formation of multiwalled tubes that provide active sites for covalently adhering chemical substances.

The resulting outcomes are expected by adopting the relevant techniques.

Incorporation of hydrocarbons results in modification of chemical composition of HNTs surface, by minimizing the polarity of HNTs surface, safeguarding the surface hydroxyl group, and lastly, by generating the functional groups on the surface of HNTs. Poikelispaa et al. reported that the dispersion property of the HNTs can be enhanced in the solvents and polymers by booming their interfacial interactions [35].

Modification of HNTs with 2-hydroxybenzoic acid [23]. HNTs were modified by Li et al. in 2008, by dissolving $2.8 \mathrm{~g}$ of 2-hydroxybenzoic acid (HBA) in $100 \mathrm{~mL}$ absolute ethanol and $4.5 \mathrm{~g}$ of HNT-3aminopropyltriethoxysilane (APTES) was suspended in a mixture with continuous heating and stirring, adding $4 \mathrm{~g}$ of $\mathrm{N}, \mathrm{N}^{\prime}$-Dicyclohexylcarbodiimide (DCC) to the suspension and then kept at reflux for $48 \mathrm{~h}$ at $86^{\circ} \mathrm{C}$. The obtained product was filtered and washed with absolute ethanol and dried in an oven for $12 \mathrm{~h}$ at $60^{\circ} \mathrm{C}$.

Silane Coupling. By condensation process, the most common covalent modification of HNTs is to graft silanes between the surface hydroxyl group of halloysite and hydrolyzed silane. Modification of the internal surface is significant for immobilization and controlled release process, whereas the modification on the external surface and edges benefits the nanocomposite applications. Yuan et al. in 2008 modified halloysite clay nanotubes by grafting with $\gamma$-aminopropyltriethoxysilane (APTES) [48].

Halloysite modification by Hexa-decyl-tri-methylammonium bromide [18]. HNTs were modified by Khunova et al. in 2013. A 5\% solution of Hexadecyl-tri-methyl-ammonium bromide (HEDA) was used for the treatment of purified HNTs at $80^{\circ} \mathrm{C}$ for $24 \mathrm{~h}$, followed by filtration and drying of HNTs in oven at $60^{\circ} \mathrm{C}$ for $24 \mathrm{~h}$ to obtain the modified HNTs. The numerous types of silanes used for modifications of HNTs are listed in Table II [22].

Table II

Silanes used for modifications of HNTs [22]

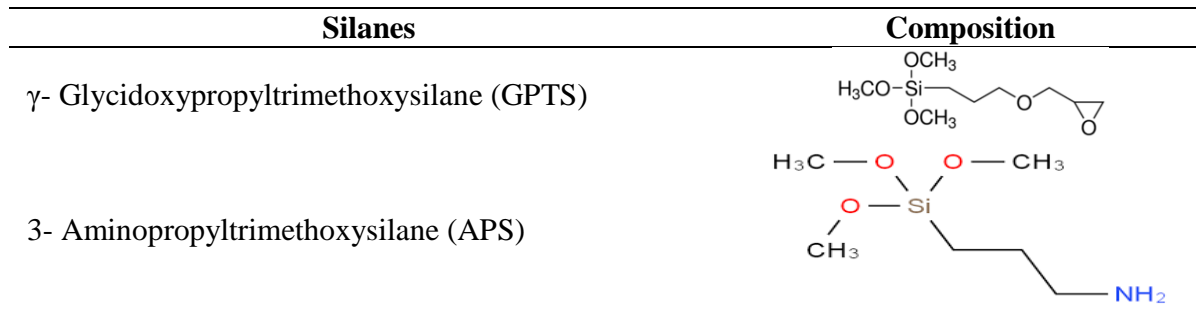


FARMACIA, 2021, Vol. 69, 2

\begin{tabular}{ll}
\hline \multicolumn{1}{c}{ Silanes } & \\
3- Aminopropyltriethoxysilane (APTES) & 3-(2-Aminoethylamino)propyl] \\
trimethoxysilane (AEAPS) & 3-(Trimethoxysilyl)propyl methacrylate (MAPTS) \\
Vinyltrimethoxysilane (VTMS) & Composition \\
\hline
\end{tabular}

\section{Non-covalent functionalization}

Non-covalent functionalization is the most efficient approach to disperse the tubes in aqueous and nonaqueous solvents without damaging their unique structure and thus retaining their intrinsic properties [47].

Characterization of HNTs. HNTs are characterized by using scanning electron microscope (SEM), scanning force microscope (SFM) and transmission electron microscope (TEM). As reported, these techniques explains that most of the samples have cylindrical tubes with 40 - $50 \mathrm{~nm}$ diameter and 0.5 - $2 \mu \mathrm{m}$ length. TEM images apparently illustrate the empty lumen of HNTs having a diameter of $15-20 \mathrm{~nm}$ [43].

Loading techniques in HNTs. There are few methods of loading drugs into HNTs and preferred methods are depicted in Figure 4.

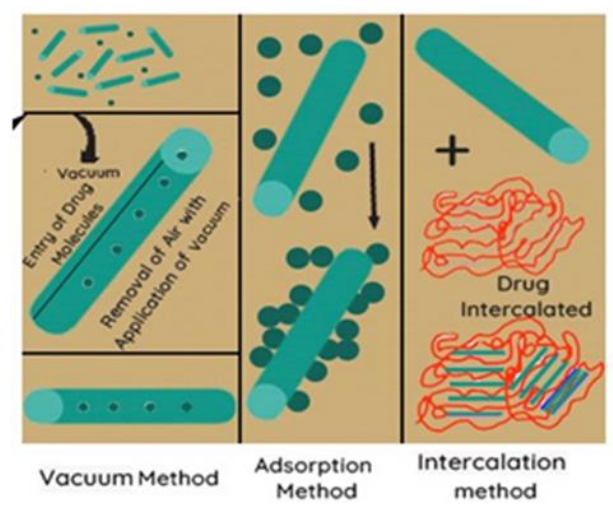

Figure 4.

Drug Loading Techniques of HNTs

Adsorption. The functional groups present on the surface of the HNTs such as Si-OH and Al-OH groups assist in determining the adsorption mechanism of HNTs. The surface charge of HNTs at pH 3 is positive, whereas above this $\mathrm{pH}$ it is negatively charged. An ionic pollutant does not possess high affinity for HNTs, as a result of negatively charged surfaces placed on the outer surfaces [19].

Intercalation. HNTs has the capacity to intercalate a wide number of organic and inorganic substances within the interlayer spaces. In this process, as the molecules penetrate the interlayer space, there is an origin of enlargement of these layers, due to the integration of water in the inter-lamellar spaces. The enlargement of these layers contributes to increase in $\mathrm{d}_{001}$ spacing between the layers [20]. The main criteria for developing the intercalation process are to entrap the water molecules between the walls of halloysite layers [13].

Tubular Entrapment. The most extensive and widely used method for loading of drug into HNTs is tubular entrapment method. It is also commonly known as vacuum method. This method was proposed by Kelly et al. in 2004 [16].

\section{Applications of HNTs}

Biomedical Applications of HNTs

Tissue Engineering Scaffolds. Tissue engineering scaffolds are components made of polymeric biomaterials to provide the structural support for cell attachment and subsequent tissue development [7]. HNTs are the rising materials in the field of tissue engineering, as they satisfy certain pre-requisites to be an ideal scaffold [26]. Zhou et al. in 2012 [25] fabricated halloysite-chitosan scaffolds by using freeze drying method. The halloysite-chitosan scaffold has revealed enhanced compressive strength, modulus, and thermal stability and has not induced any cytotoxicity as compared to pure chitosan scaffold. Hence, HNTs polymer nanocomposite shows great potential for applications in tissue engineering.

HNTs as Wound Healing Sponges. Properties such as mechanical strength, good biocompatibility and haemostasis of tubular HNTs makes them ideal candidate for wound healing applications. HNTs-based nanocomposite are tuned into dressings with wound healing properties. The porous and flexible chitosan composite sponges were fabricated by addition of HNTs which resulted in increased elastic modulus, compressive strength and toughness. Liu et al. have formulated chitosan-HNTs nanocomposite sponge by imposing freeze drying method. It was observed that the HNTs improved chitosan's blood clotting ability [27].

HNTs for Bone implant/Bone cement. Bone grafting is a surgical process which reinstates the missing bone in order to restore bone fractures. The most efficiently 
available bone implants are dental implants and devices used in the improvement of damaged bones. The most extensively used bone cement is poly (methyl methacrylate) (PMMA) as it showed magnificent biocompatibility and mechanical properties for arthroplasty [39]. The bone cement is fabricated by incorporating the PMMA with gentamycin loaded HNTs. Thus, the PMMA/HNTs/gentamycin composite offered consistent sustained release up to $300-400 \mathrm{~h}$ and hence there by maintaining extended antibacterial protection [28].

HNTs for Cancer Cell Isolation. Curcumin is the most significant drug possessing the anti-inflammatory and anticancer properties and hence several methods have been adopted to load the curcumin into the lumen of HNTs. Massaro et al. in 2013 have reported that drug loading is carried out by functionalization of positively charged HNTs using tetrazolium salts. These HNTs-based carriers of curcumin were used as drug delivery for different cell line studies and were proved to be effective in many of cancer cells [36].

HNTs as potential Drug delivery vehicles. The most effective site for drug entrapment is the nanopore of HNTs [9]. The surface of drug loaded HNTs can be further coated with different polymers to achieve better delayed drug release rates [10]. Drugs, proteins and different substances can be loaded into the clay tube [2]. The chitosan and polyethyleneimine (PEI) coated HNTs reveal delayed release rates compared to uncoated HNTs [3], Figure 5.

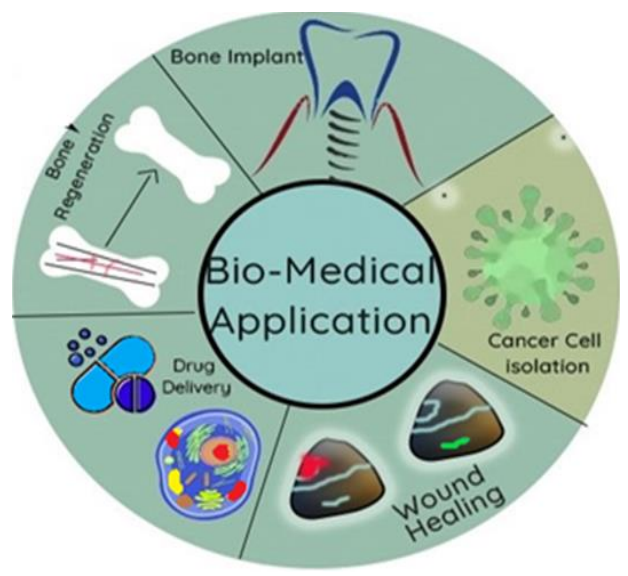

Figure 5.

Biomedical Applications of HNTs

Halloysite nanotubes possess wide range of biomedical applications such as in tissue engineering (bone regeneration), drug delivery, wound healing, bone implant and cancer cell isolation

\section{HNTs for Non-Biomedical Applications}

Use of HNTs as Nanoreactors and Nanocontainers Nanoreactors

Nanoparticles and nanowires can be formulated by employing HNTs as nanoreactors. Synthesis of enzymecatalysed inorganic reaction can be carried out by using HNTs bio-mineralization reactors, whereas HNTs lumen behaves as biomimetic nanoreactor [1].

\section{Nanocontainers}

Anti-Corrosion Coating with Benzotriazole. Corrosion of metals is a crucial technical problem. HNTs are used as tubular sacs for benzotriazole which is considered as corrosion inhibitor [48].

Use of HNTs in the synthesis of silver nanorods Silver nanorods were fabricated by thermal decomposition of silver acetate from its aqueous solution and loaded into the lumen of the halloysite, by employing the vacuum cycling process. The polymer composite of silver nanorods revealed antimicrobial activity and increased tensile strength [42].

Gold Nanoparticles

Gold nanoparticles were prepared by reduction of chloroauric acid $\left(\mathrm{HAuCl}_{4}\right)$ using HNTs. Gold nanoparticles possess large surface area, which promotes high drug loading efficiency, biocompatible, and are freely accessible for the conjugation with biomolecules. These are non-cytotoxic to normal cells [17]. Application of HNTs for in situ chemical polymerization The polyaniline (PANI) is laminated on the facet of the HNTs by adopting in situ soapless emulsion polymerization of anilinium chloride adsorbed on HNTs. Ammonium persulfate (APS), an oxidant, is used to roll out the HNTs in an aqueous solution of aniline with constant stirring and ultrasonic irradiation. The acidity of polymerizing media and adsorptivity of anilinium chloride on the surface of HNTs modify the structural characteristics of PANI/HNTs nanocomposites [51].

HNTs for Cosmetic Application

As a result of elongated hollow tubular structure and strong absorption capacity, HNTs can be availed as cleansing masks, which promote deep purification and clears the facial pores. The hollow HNTs can be loaded with a variety of active ingredients; particularly those used in cosmetics, household and personal care products [44], as shown in Figure 6.

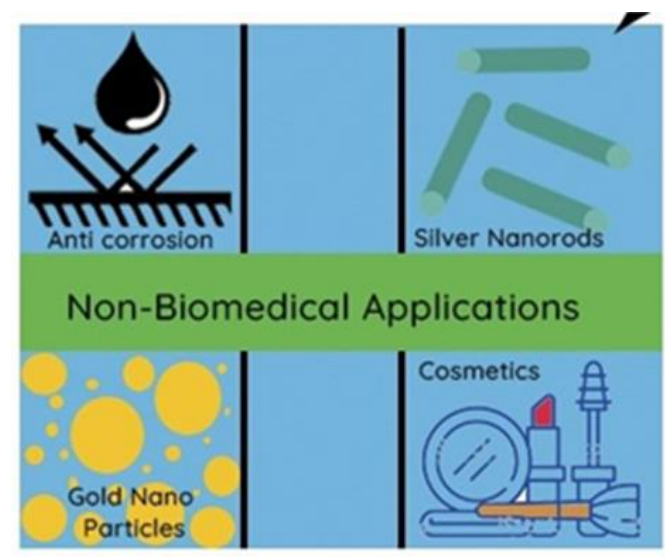

Figure 6.

Non-Biomedical Applications of HNTs

Halloysite nanotubes have non-biomedical applications; therefore they can be used as anti-corrosive agent, cosmetics, in the fabrication of silver nanorods and gold nanoparticles 


\section{Conclusions}

This review highlights the structural features, functionalization, biomedical and non-biomedical applications of HNTs. HNTs display remarkable thermal stability, faster adsorption rates, tuneable release rates, excellent drug encapsulation, biocompatibility, mechanical properties, and ease of availability therefore with numerous pharmaceutical applications. The functionalization of HNTs is a main necessity for processing and promoting the properties of HNTs polymer composites. HNTs have also established prominent character in various fields of biomedical sciences such as tissue engineering, bone implants, fillers in bone cement, and cancer cell isolation. Apart from biological features, HNTs have played roles in the synthesis of silver and gold nanoparticles, nanoreactors and nanocontainers, cosmetics, and drug delivery. Thus, it can be concluded that HNTs have acquired promising anticipation in the development of new structural and functional materials to emerge as trendsetters for green nanotechnology.

\section{Conflict of interest}

The authors declare no conflict of interest.

\section{References}

1. Abdullayev E, Price R, Shchukin D, Lvov Y, Halloysite tubes as nanocontainers for anticorrosion coating with benzotriazole. ACS Appl Mater Interfaces, 2009; 1(7): 1437-1443.

2. Abdullayev E, Joshi A, Wei W, Zhao Y, Lvov Y, Enlargement of halloysite clay nanotube lumen by selective etching of aluminum oxide. ACS Nano, 2012; 6(8): 7216-7226.

3. Abdullayev E, Abbasov V, Tursunbayeva A, Portnov V, Ibrahimov H, Mukhtarova G, Lvov Y, Self-healing coatings based on halloysite clay polymer composites for protection of copper alloys. ACS Appl Mater Interfaces, 2013; 5(10): 4464-4471.

4. Buruga K, Kalathi JT, Fabrication of $\gamma$-MPS-Modified HNT-PMMA Nanocomposites by Ultrasound-Assisted Miniemulsion Polymerization. JOM., 2018; 70(7): 1307-1312.

5. Del Buffa S, Bonini M, Ridi F, Severi M, Losi P, Volpi S, Al Kayal T, Soldani G, Baglioni P, Design and characterization of a composite material based on $\mathrm{Sr}$ (II)-loaded clay nanotubes included within a biopolymer matrix. J Colloid Interface Sci., 2015; 448: 501-507.

6. Deng S, Zhang J, Ye L, Halloysite-epoxy nanocomposites with improved particle dispersion through ball mill homogenization and chemical treatments. Compo Sci Technol., 2009; 69(14): 2497-2505.

7. Fakhrullin RF, Lvov YM, Halloysite clay nanotubes for tissue engineering. Nanomedicine (Lond.), 2016; 11(17): 2243-2246.

8. Ferrari PC, Araujo FF, Pianaro SA, Halloysite nanotubes-polymeric nanocomposites: characteristics, modifications and controlled drug delivery approaches. Cerâmica, 2017; 63(368): 423-431.
9. Fizir M, Dramou P, Dahiru NS, Ruya W, Huang T, $\mathrm{He} \mathrm{H}$, Halloysite nanotubes in analytical sciences and in drug delivery: A review. Microchimica Acta, 2018; 185(8): 389: 1-33.

10. Forsgren J, Jämstorp E, Bredenberg S, Engqvist H, Strømme M, A ceramic drug delivery vehicle for oral administration of highly potent opioids. J Pharma Sci., 2010; 99(1): 219-226.

11. Fulekar MH, Pathak B, Environmental Nanotechnology. CRS Press Taylor and Francis Group, 2017; 93-94.

12. Gray N, Lumsdon DG, Hillier S, Effect of $\mathrm{pH}$ on the cation exchange capacity of some halloysite nanotubes. Clay Miner, 2016; 51(3): 373-383.

13. Hanif M, Jabbar F, Sharif S, Abbas G, Farooq A, Aziz M, Halloysite Nanotubes as a new drug-delivery system: A Review. Clay Miner, 2016; 51(3): 469-477.

14. Kamble R, Ghag M, Gaikawad S, Panda BK, Halloysite Nanotubes and Applications: A Review. J Adv Sci Res., 2012; 3(2): 25-29.

15. Kausar A, Review on polymer/halloysite nanotubes nanocomposite. Poly-Plast Tech Eng., 2018; 57(6): 548-564.

16. Kelly HM, Deasy PB, Ziaka E, Claffey N, Formulation and preliminary in vivo dog studies of a novel drug delivery system for the treatment of periodontitis. Int J Pharma., 2004; 274(1-2): 167-183.

17. Khan AK, Rashid R, Murtaza G, Zahra A, Gold nanoparticles: synthesis and applications in drug delivery. Trop J Pharma Res., 2014; 13(7): 1169-1177.

18. Khunova V, Kristóf J, Kelnar I, Dybal J, The effect of halloysite modification combined with in situ matrix modifications on the structure and properties of polypropylene/halloysite nanocomposites. eXPRESS Poly Lett., 2013; 7(5): 471-479.

19. Kiani G, High removal capacity of silver ions from aqueous solution onto halloysite nanotubes. Appl Clay Sci., 2014; 90: 159-164.

20. Krejčová K, Deasy PB, Rabišková M, Diclofenac sodium entrapment and release from halloysite nanotubules. Ceska Slove Farma., 2013; 62(1): 28-34.

21. Kruif JK, Ledergerber G, Garofalo C, Fasler-Kan E, Kuentz M, On prilled nanotubes-in-microgel oral systems for protein delivery. Eur J Pharma Biopharma., 2016; 101: 90-102.

22. Li C, Liu J, Qu X, Guo B, Yang Z, Polymer-modified halloysite composite nanotubes. J Appl Poly Sci., 2008; 110(6): 3638-3646.

23. Li R, Hu Z, Zhang S, Li Z, Chang X, Functionalized halloysite nanotubes with 2-hydroxybenzoic acid for selective solid-phase extraction of trace iron (III). Int J Environ An Chem., 2013; 93(7): 767-779.

24. Liu M, Guo B, Zou Q, Du M, Jia D, Interactions between halloysite nanotubes and 2, 5-bis (2benzoxazolyl) thiophene and their effects on reinforcement of polypropylene/halloysite nanocomposites. Nanotechnol., 2008; 19(20): 205709: 1-10.

25. Liu M, Zhang Y, Wu C, Xiong S, Zhou C, Chitosan/halloysite nanotubes bionanocomposites: structure, mechanical properties and biocompatibility. Int J Biomed Macromol., 2012; 51(4): 566-575.

26. Liu M, Wu C, Jiao Y, Xiong S, Zhou C, Chitosanhalloysite nanotubes nanocomposite scaffolds for tissue engineering. J Mater Chem B., 2013; 1(15): 2078-2089. 
27. Liu M, Shen Y, Ao P, Dai L, Liu Z, Zhou C, The improvement of hemostatic and wound healing property of chitosan by halloysite nanotubes. RSC $A d v$., 2014; 4(45): 23540-23553.

28. Luo BH, Hsu CE, Li JH, Zhao LF, Liu MX, Wang XY, Zhou CR, Nano-composite of poly (L-lactide) and halloysite nanotubes surface-grafted with Llactide oligomer under microwave irradiation. J Biomed Nanotechnol., 2013; 9(4): 649-658.

29. Lvov Y, Abdullayev E, Functional polymer-clay nanotube composites with sustained release of chemical agents. Prog Poly Sci., 2013; 38(10-11): 1690-1719.

30. Lvov Y, Aerov A, Fakhrullin R, Clay nanotube encapsulation for functional biocomposites. Adv Colloid Interface Sci., 2014; 207: 189-198.

31. Massaro M, Lazzara G, Milioto S, Noto R, Riela S, Covalently modified halloysite clay nanotubes: synthesis, properties, biological and medical applications. $J$ Mater Chem B., 2017; 5(16): 2867-2882.

32. Mingliang Du, Baochun G, Demin J, Newly emerging applications of halloysite nanotubes: a review. Soci Chem Indus., 2010; 59(5): 574-582.

33. Mohtashim H Shamsi, Kurt E Geckeler, The first biopolymer-wrapped non-carbon nanotubes. Nanotechnol., 2008; 19(7): 075604.

34. Nano by Nature, (Bernhardt Fudmya Design Group), www.bfdg.com, 2011.

35. Poikelispää M, Das A, Dierkes W, Vuorinen J, Synergistic effect of plasma-modified halloysite nanotubes and carbon black in natural rubberbutadiene rubber blend. J Applied Poly Sci., 2013; 127(6): 4688-4696.

36. Riela S, Massaro M, Colletti CG, Bommarito A, Giordano C, Milioto S, Noto R, Poma P, Lazzara $\mathrm{G}$, Development and characterization of co-loaded curcumin/triazole-halloysite systems and evaluation of their potential anticancer activity. Int J Pharm., 2014; 475: 613-623.

37. Saif MJ, Asif HM, Escalating applications of halloysite nanotubes. J Chil Chem Soc., 2015; 60(2): 2949-2953.

38. Saif MJ, Asif HM, Naveed M, Properties and modification methods of halloysite nanotubes: a stateof-the-art review. J Chil Chemi Soc., 2018; 63(3): 4109-4125.

39. Santos AC, Ferreira C, Veiga F, Ribeiro AJ, Panchal A, Lvov Y, Agarwal A, Halloysite clay nanotubes for life sciences applications: From drug encapsulation to bioscaffold. Adv Colloid Interface Sci., 2018; 257: 58-70.

40. Santos AC, Pereira I, Reis S, Veiga F, Saleh M, Lvov Y, Biomedical potential of clay nanotube formulations and their toxicity assessment. Exp Opin Drug Deliv., 2019; 16(11): 1169-1182.

41. Shchukin DG, Sukhorukov GB, Price RR, Lvov YM, Halloysite nanotubes as biomimetic nanoreactors. Small, 2005; 1(5): 510-513.

42. Shchukin DG, Lamaka SV, Yasakau KA, Zheludkevich ML, Ferreira MG, Möhwald H, Active anticorrosion coatings with halloysite nanocontainers. $J$ Physi Chem C., 2008; 112(4): 958-964.

43. Singh B, Why does halloysite roll?-A new model. Clays Clay Miner, 1996; 44(2): 191-196.

44. Sun YJ, Kil DS, Chung KS, Abdullayev E, Lvov YM, Mongayt D, Natural nanocontainer for the controlled delivery of glycerol as a moisturizing agent. J Nanosci Nanotechnol., 2011; 11(1): 661-665.

45. Suvendhu P, P Ganga Raju Achary, Nimai C Nayak, Mechanical and morphological properties of halloysite nanotubes filled ethylene-vinyl acetate copolymer nanocomposites. Indian J Chem Technol., 2017; 24: 184-191.

46. White RD, Bavykin DV, Walsh FC, The stability of halloysite nanotubes in acidic and alkaline aqueous suspensions. Nanotechnol., 2012; 23(6): 065705.

47. Wilson IR, Santos HD, Santos PD, Kaolin and halloysite deposits of Brazil. Clay Miner, 2006; 41(3): 697-716.

48. Yuan P, Southon PD, Liu Z, Green ME, Hook JM, Functionalization of halloysite clay nanotubes by grafting with $\gamma$-aminopropyltriethoxysilane. J Phys Chem C., 2008; 112(40): 15742-15751.

49. Yuri M Lvov, Dmitry G Shchukin, Helmuth Möhwald, Ronald R Price, Halloysite Clay Nanotubes for Controlled Release of Protective Agents. ACS Nano, 2008; 2(5): 814-820.

50. Yuri L, Ronald P, Halloysite nanotubes applications in nanomaterials research. Merck. www.sigmaaldrich.com/.

51. Zhang L, Wang T, Liu P, Polyaniline-coated halloysite nanotubes via in-situ chemical polymerization. Appl Surf Sci., 2008; 255(5): 2091-2097. 